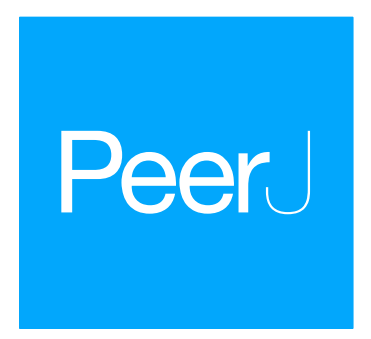

\title{
The role of biomaterials in the treatment of meniscal tears
}

\author{
Crystal O. Kean ${ }^{1, *}$, Robert J. Brown ${ }^{2}$ and James Chapman ${ }^{1, *}$ \\ ${ }^{1}$ School of Health, Medical and Applied Sciences, Central Queensland University, Rockhampton, Queensland, \\ Australia \\ ${ }^{2}$ Advanced Medical Solutions, Plymouth, UK \\ These authors contributed equally to this work.
}

\section{ABSTRACT}

Extensive investigations over the recent decades have established the anatomical, biomechanical and functional importance of the meniscus in the knee joint. As a functioning part of the joint, it serves to prevent the deterioration of articular cartilage and subsequent osteoarthritis. To this end, meniscus repair and regeneration is of particular interest from the biomaterial, bioengineering and orthopaedic research community. Even though meniscal research is previously of a considerable volume, the research community with evolving material science, biology and medical advances are all pushing toward emerging novel solutions and approaches to the successful treatment of meniscal difficulties. This review presents a tactical evaluation of the latest biomaterials, experiments to simulate meniscal tears and the state-of-the-art materials and strategies currently used to treat tears.

Submitted 5 June 2017

Accepted 31 October 2017

Published 17 November 2017

Corresponding author

James Chapman,

j.chapman@cqu.edu.au

Academic editor

Laura Guidetti

Additional Information and Declarations can be found on page 16

DOI 10.7717/peerj.4076

Copyright

2017 Kean et al.

Distributed under

Creative Commons CC-BY 4.0

OPEN ACCESS
Subjects Biotechnology, Kinesiology, Orthopedics

Keywords Knee meniscus; biomaterials, Tissue engineering, Materials science, Scaffolds, Biomaterials

\section{INTRODUCTION}

The knee is considered a hinge joint; however, because it also features characteristics of an arthrodial joint, it is a more complex joint than other hinge joints such as the elbow and ankle. The knee consists of two articulations which form the tibiofemoral joint (further separated into the medial and lateral tibiofemoral joints) and the patellofemoral joint. The articulations are not entirely congruent and this arrangement allows for the combination of gliding and rolling motions which is constrained mainly by the ligaments of the knee. The menisci are fibrocartilagenous structures that sit on top of tibia to deepen the plateaus with the primary functions transmitting load through the joint and also serve to increase joint stability and lubrication of the articular cartilage (Seedhom, Dowson \& Wright, 1974; Walker \& Erkman, 1975; McDermott, Masouros \& Amis, 2008).

The menisci are commonly injured due to traumatic events and/or degenerative stresses. In the United States alone, it was estimated that approximately 6.6 million patient visits to the emergency department between 1999 and 2008 were due to knee injuries equating to 2.29 knee injuries per 1,000 people (Gage et al., 2012; Reid et al., 2017). Furthermore, by 2060 the percentage of people reaching an age of 50 will reach $50 \%$ representing a change in population demographic and likelihood for pressures in the knee. A large proportion of 
knee injuries in the general population are meniscal related and meniscal injuries are even more common in a physically active population (Baker et al., 1985; Nielsen \& Yde, 1991). Given the role meniscal tears, and subsequent partial or full removal of the meniscus, play in development of osteoarthritis (Englund, Roos \& Lohmander, 2003; Roos et al., 1998) there is an increased interest in preservation of these structures following injury. For this reason, there is also an increased interest the role biomaterials play in meniscal repair, regeneration and replacement options.

Advances in materials technology have brought about an increased usage of biomaterials and medical devices in the body (Hallab, Link \& McAfee, 2003; Chevalier, 2006; Yamamoto, Takagi \& Ito, 2016). A biomaterial is a material or substance or combination of substances, other than drugs, synthetic or natural in origin, which can be used for any period of time (Bochynska et al., 2016c; Brannigan \& Dove, 2017; Kaur, 2017), which augments or replaces partially or totally any tissue, organ or function of the body in order to improve the quality of life of an individual (Bergmann \& Stumpf, 2013). The biomaterial must be able to interact with the surrounding human tissue and body fluids to improve or replace the anatomical defect. Some examples of the recent advances for biomaterial use in medicine include knee and hip replacement (Walczak, Shahgaldi \& Heatley, 1998; Bahraminasab \& Farahmand, 2017), ocular implants (Lloyd, Faragher \& Denyer, 2001; Baino et al., 2017; Mota et al., 2017), heart valves (Vongpatanasin, Hillis \& Lange, 1996; Vander Roest \& Merryman, 2016; Emmert \& Hoerstrup, 2017), bone implants (Bròdano et al., 2014; Apicella et al., 2017), dental implants (Tamimi et al., 2014), biosensors (Sun et al., 2014; Calvo et al., 2017), orthopaedic screws and sutures (Waizy et al., 2014; Zhao et al., 2017) and tissue allografts (Cameron \& Saha, 1997; Sanen et al., 2017). The achievements, in terms of biocompatibility, to lower risk of failure and improved surgical outcomes have contributed to the expanding use of biomaterials. For these reasons advancements in biomaterial development is and has been a significantly fast-growing area of research.

This review article will focus on providing a general review of the menisci and meniscal injuries. We also discuss biomaterials and the subsequent role biomaterials play in the surgical treatment options for meniscal repair, regeneration and replacement as well as future directions. While other reviews have been developed, their focus has been to provide an overview of materials only, this review provides significant detail on cell lines used, models and materials to support research momentum for future developmental medical breakthroughs.

\section{MENISCUS}

\section{Biomechanics and function}

The menisci are fibrocartilage structures, composed mainly of type 1 collagen, that sit on top of tibia, Fig. 1.

The lateral meniscus (e) is a C-shaped structure that covers approximately $80 \%$ of the lateral tibial plateau whereas the medial meniscus (c) is a U-shaped structure and covers only $60 \%$ of the medial tibial plateau. The menisci are relatively avascular with only $10-30 \%$ of the peripheral region of the medial meniscus and $10-25 \%$ of the lateral meniscus 


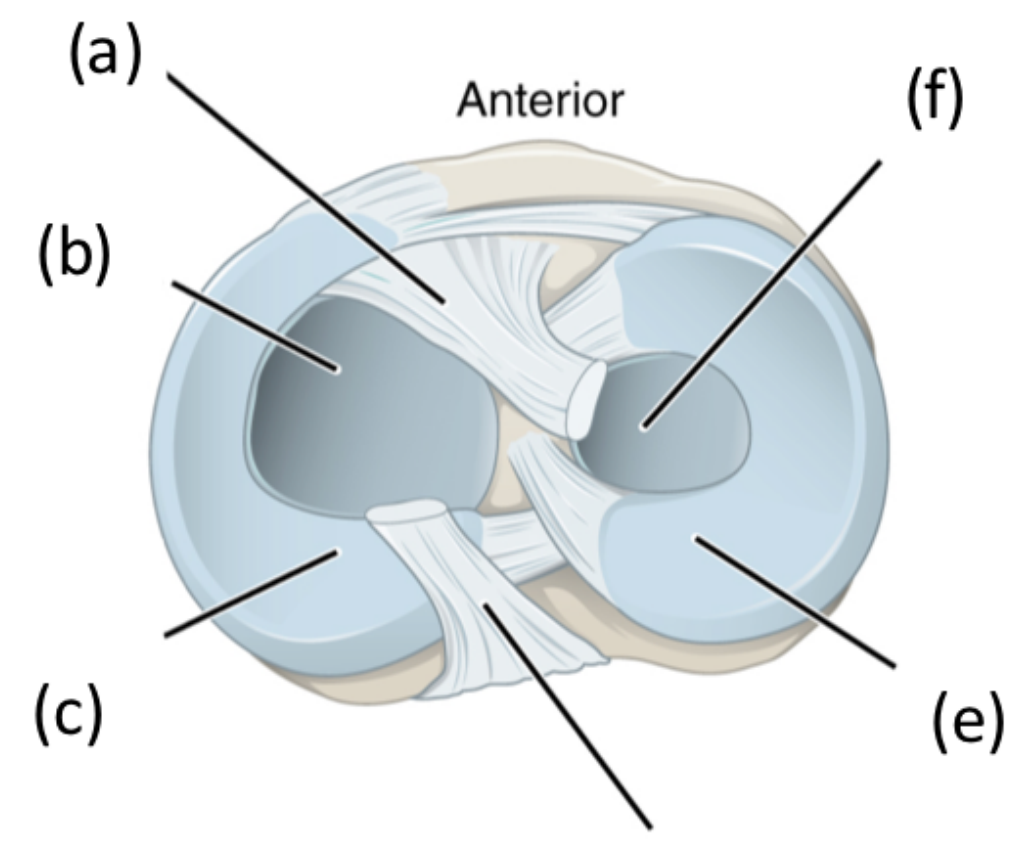

(d)

Figure 1 Superior view of the right tibia in the knee joint illustrating the menisci and cruciate ligaments. (A) anterior cruciate ligament, (B) articular cartilage on medial tibial condyle, (C) medial meniscus, (D) posterior cruciate ligament, (E) lateral meniscus, (F) articular cartilage on lateral tibial condyle. Full-size DOI: $10.7717 /$ peerj.4076/fig-1

being vascular (Arnoczky \& Warren, 1982). Based on its vascularisation, the menisci can be divided into three zones: the red-red vascular zone (outer peripheral region), the white-white avascular zone (inner region) and the red-white zone which lies between of the two other zones and has characteristics of other two zones. The red vascular region is thick and convex and attaches to the capsule of the joint whereas the white-white inner region is thin, concave and is a free edge unattached to the joint.

The menisci effectively deepen the tibial plateau and allow smooth articulation between the tibial and femoral condyles and the transmission of loads across the tibiofemoral joint. In full knee extension, the medial meniscus transmits approximately $50 \%$ of the load on the medial compartment, while lateral meniscus transmits approximately $70 \%$ of the load in the lateral compartment (Walker \& Erkman, 1975). As knee flexion increases the amount of load transmitted to the lateral meniscus increases such that when the knee is flexed beyond $75^{\circ}$ the entire load that passes through the lateral compartment, is transmitted by the lateral meniscus (Walker \& Erkman, 1975). For the medial meniscus the increase in load transmission as the knee flexes is less apparent (Walker \& Erkman, 1975). When the meniscus is intact, the load is well distributed across the tibiofemoral compartment; however when part or the entire meniscus is removed there is considerable alterations to load distribution such that there is a decrease in the contact area and increases in peak contact forces (Bedi et al., 2012; Lee et al., 2006; Ihn, Kim \& Park, 1993). 


\section{Meniscal tears}

Meniscal tears are one of the most common intra-articular knee injuries (Clayton \& Court-Brown, 2008; Majewski, Susanne \& Klaus, 2006) and is typically the result of an axial loading and rotational forces which result in a shear load on the meniscus (Browner, 2009). This may be a result of a traumatic event or cumulative stress leading to degenerative tears. The medial meniscus is more often injured than the lateral (Majewski, Susanne \& Klaus, 2006); however, lateral meniscal tears are more often associated with acute ACL tear (Bellabarba, Bush-Joseph \& Bach Jr, 1997). Although there is no uniformly accepted classification of meniscal tears, the classifications typically involve a description of the tear pattern and location. Common tear patterns that typically originate from traumatic events include longitudinal, bucket-handle, and radial tears (Greis et al., 2002). Whereas horizontal, flap and complex tears are typically seen in older adults and due to cumulative stress resulting in degeneration (Greis et al., 2002). The location of the tears may be classified based on the zone classification system purposed by Cooper, Arnoczky \& Warren (1990) in which the menisci are divided into three radial zones (anterior, medial and posterior) and four circumferential zones (meniscosynovial junction or periphery, outer third, middle third and inner third of the menisci) (Fig. 2).

In a similar fashion to the zone classifications, tears may be graded as partial or fullthickness tears or using a grading scheme $0-$ III in which 0 indicates a normal intact menisci and III a full-thickness tear (Cooper, Arnoczky \& Warren, 1990; Pihl et al., 2017).

\section{Available treatment options}

Meniscal tears account for a significant portion of surgical procedures performed by orthopaedic surgeons, the patient experiences significant pain and sometimes complete disability from these tears and resulting procedures (Berthiaume et al., 2005). The surgical procedures involved in the treatment of a meniscal tear may include a partial or full meniscectomy or a meniscal repair. The meniscectomy procedures involve either part or all of the damaged meniscus being removed which in turn leads to higher rates of osteoarthritis in subsequent years. Surgical treatment of meniscal injuries has undergone a number of developments over the past two decades, moving from open arthroscopic surgery; from total to partial meniscectomy and adding novel treatments; such as repair using a variety of devices, materials, transplants, collagen implants or xenografts (Kim et al., 2013; Jiang et al., 2012; Grogan et al., 2017; Baek et al., 2017). If meniscectomy takes place or insisted upon, this procedure is mainly due to changes in load distribution across the articular cartilage as studies have shown that following total meniscectomy peak contact pressures increase by $253 \%$ and $165 \%$ following partial meniscectomy (Lee et al., 2006; Baratz, Fu \& Mengato, 1986; Beamer et al., 2017; Van Egmond et al., 2017). Following meniscectomy, there is also evidence of reduced muscle strength, altered gait patterns and clinical outcomes (Hall et al., 2013; Hall et al., 2014; McLeod et al., 2012; Sturnieks et al., 2008a; Sturnieks, Besier \& Lloyd, 2011; Sturnieks et al., 2008b; Salata, Gibbs \& Sekiya, 2010; Scholes et al., 2017). For these reasons, there are an increasing number of interests in performing meniscal repair. What needs to be remembered is that not all meniscal tears are suitable for repair, and thus other treatment options such as meniscal replacement 


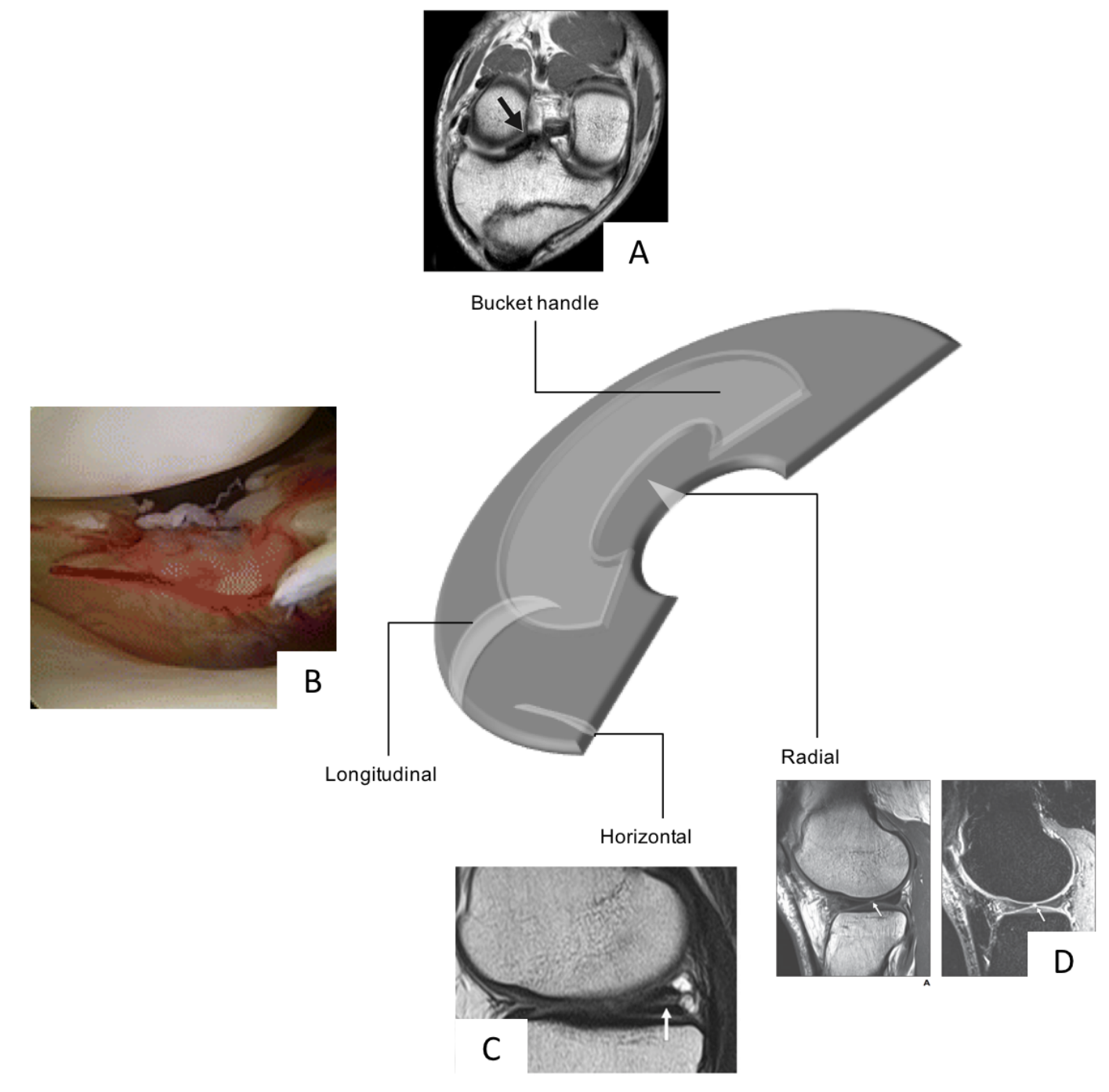

Figure 2 Schematic diagram highlighting the various types of meniscal tears, Bucket Handle MRI image taken from Han et al. (2015) (CC BY NC 3.0), Radial Tear, MRI image taken from Jung et al. (2012), and longitudinal (photograph taken from Feucht et al. (2015) (CC BY 4.0)) and horizontal tears (MRI taken from Ohishi et al. (2010) (CC BY 2.0)) all with permission.

Full-size DOI: $10.7717 /$ peerj.4076/fig-2

and regeneration are of considerable interest when a surgical intervention is necessary to improve any pain and symptoms.

\section{BIOMATERIALS}

Current treatment modalities for meniscal repair tears still carry their drawbacks and novel, robust and effective solutions are required. Some recent advances in meniscus research suggest that low cellularity, (King et al., 2017) dense ECM and poor vascularisation coupled with the inflammatory responses (King et al., 2017) in the knee joint are responsible for a lack of healing. Recently, biomaterials in the form of tissue adhesives have become available for clinical use: fibrin glue, (Bochyńska et al., 2016a) TissuGlu ${ }^{\circledR}$, 
Dermabond ${ }^{\circledR}$, (Balakrishnan et al., 2017) where the development of these new adhesive biomaterials has improved the properties of existing biomaterials alone (TissuGlu ${ }^{\circledR}$, Raleigh, NC, USA; Ethicon Inc., Somerville, NJ, USA). Furthermore, these materials and strategies are not always a given success, presenting limitations to the accomplishment of the meniscal reparation.

\section{Tissue engineering using biomaterials}

Of late, tissue-engineering and cellular biomaterial interactive concepts have been introduced to develop cellular-based reparation for cartilage regeneration (Temenoff \& Mikos, 2000). The type of cell used to engineer cartilage is critical as a future goal of biomaterial development. Various cell populations that have been investigated for these roles include: chondrocytes (King et al., 2017; Chen \& Cheng, 2006), mesenchymal stem cells, bone marrow stromal cells and perichondrocytes (Bruns et al., 1998). The choice of biomaterial is critical to the success of tissue engineering approaches for cartilage repair. The concept of 'tissue engineering' was first introduced and postulated by Green Jr (1977) where chondrocytes grown ex vivo could be transplanted into a region of tissue defect. Recently, tissue and biomaterial engineering concepts have been initiated to develop cellular based approaches for tissue repair (Freed et al., 1993). Typically, the process for engineering tissue involves the isolation of chondrocytes which are then seeded into a biocompatible matrix or scaffold and finally cultivated for implantation into the defected region. A large variety of biomaterials, natural and synthetic, have been employed as potential cell-carriers for tissue regeneration. The most common naturally occurring materials include type I and type II collagen-based biomaterials. Furthermore, some of the contrasting synthetic approaches include: polyglycolic acid or poly-L-lactic acid or other various composite mixtures (Chen \& Cheng, 2006). In essence, an ideal candidate biomaterial would be a cell-carrier substance which closely mimics the natural environment in the surrounding matrix-as given by the definition of a biomaterial.

Regenerative approaches to meniscus repair occurs in a series of precise stages. It is typically understood that the low cellularity (endogenous meniscus cells and meniscus progenitors) (Mauck \& Burdick, 2015), the dense ECM, poor vascularisation potential and the inflammatory responses typically linked to meniscus wounds all contribute to the success or failure of the meniscus healing and regeneration alone. This success of healing process is without a biomaterial introduced into the site. Based on these principles, the potential use of a biomaterial to develop and deliver a viable solution requires thought around this repair process.

Biomaterials are typically promoters of tissue repair through provision of scaffold layers for cellular attachment and growth and differentiation further acting as a vehicle for protein and gene transfer to regenerate functional tissue approaches (Chen, Zhang \& Wu, 2010). Biomaterials in this area should have several properties to support viable repair. Typically, this is achieved through:

(1) The material must act as a support structure for cell lines (i.e., cells that are seeded in vitro are compatible, adhere to the material if required or certain cell lines are not required; filtered out). For meniscal repair the biomaterial must provide 
appropriate biomechanical functions after implantation to shield cells from damaging or compressive forces;

(2) Possess sufficient mechanical strength to protect the surrounding cells (cells should be mechanically stable i.e., cell attachment is maintained). For meniscal repair the biomaterial must maintain their shape and integrity, mechanical stability and strength for the defect area in question until new host tissue has been regenerated. Furthermore, it may be important to provide biological and mechanical context for cell differentiation, proliferation and attachment when a biomaterial is introduced into the knee. For example, it is now very well understood that cells are influenced by the local external environment including the adhesive and biophysical properties (Engler et al., 2006);

(3) Withstand in vivo forces during the joint movement operation (mechanical and structural stability of the biomaterial in the meniscus area needs to be able to withstand compressive and tensile forces (these forces have been aptly described in Paschos et al. (2017));

(4) Bioactivity should be provided to accommodate cellular attachment and cellular migration (the biomaterial in the meniscus will therefore be able to promote tissue regeneration). Furthermore, providing directional cues, such as chemotactic gradients to guide cells like endogenous cells to the injury site. Recently, some studies have shown that allowing migration of cells provides a motivation for the cells to attach and drives the cellular colonisation process (Mauck \& Burdick, 2015; Greiner et al., 2014);

(5) The biomaterial should have biodegradable properties and be able to remodel as the novel cartilage grows, embeds and replaces the original construct; therefore, the matrix must be non-toxic, non-adhering and non-stimulating for inflammatory cells. The biomaterial for a meniscus should therefore facilitate host tissue integration and provide the appropriate biomechanical function in the knee.

(6) Furthermore, they should be non-immunogenic as this is catastrophic for the biomaterial insertion. For any biomaterial, this is important, to prevent rejection the appropriate level of biocompatibility and non-toxic ability needs to be considered.

\section{Biocompatibility}

One of the most important non-mechanical requirements of orthopaedic biomaterials is biocompatibility. Biocompatibility is the ability of a substrate to exist in contact with tissues of the human body without causing an unacceptable degree of harm in the body. The biomaterial domain has been aptly described by Mardis and Kroeger, "the utopian state where a biomaterial presents an interface with physiologic environment without the material adversely affecting the environment or environment adversely affecting the biomaterial" (Mardis \& Kroeger, 1988). An understanding of biocompatibility requires an appreciation of tissue cell, bacterial cell and host defence response to the insertion of a biomaterial in particular for this review-for meniscal interventions. Once the biomaterial has been placed into the body, a conditioning film containing biomolecules such as; water, electrolytes, cholesterol, vitamins, lipids and proteins (Chapman et al., 2013) (albumin, igG, fibronectin, fibrinogen, laminin, collagen and osteopontin) form on the surface long before cells are present and reach the state of equilibrium (Thevenot, Hu\& Tang, 2008). 
In the very early implantation period or injury for this matter, inflammatory cells begin to proliferate, this is an immediate response (Anderson, Rodriguez \& Chang, 2008). The first contact with tissue, proteins in blood and the interstitial fluids adsorb on to the biomaterial surface. An injury to vascularised connective tissue initiates the inflammatory response but also leads to the process of thrombus formation involving the activation of the extrinsic and also intrinsic coagulation, complement, fibrinolytic, kinin-generating systems and platelets (Anderson, Rodriguez \& Chang, 2008). The conditioning layer represents a dynamic, ever-changing layer due to differential diffusion and mass transport of molecules in and out of the implant surface. Later stages of competitive binding then occur on the surface of the material owing to functional groups within the molecules. Cells therefore never see the 'true' surface of the biomaterial, but more correctly, respond and interact to a conditioned film that has consequently developed in-situ.

Following the conditioning sequence of the biomaterial, attachment cells secure themselves to the protein and protein matrices using integrin receptors. Thus, this conditioning layer is vital to the reaction of cells to the surface of the implanted biomaterial. The introduction of the biomaterial, the conditioning and immune response sequence is not always obvious as proteins have the ability to conform and expose epitopes that are not always identified as self-produced by the body's immune system. Immune cells react as they detect what were once normal proteins and recognise them as foreign bodies. This process can result in a cascade of blood coagulation and chronic inflammation that can lead to occlusion of nutrients, changes in oxygen and fibrous capsule formation-operating toward total rejection by the body of the implanted biomaterial (Nasab \& Hassan, 2010). The extent of the deformation process for proteins has been remedied based on the selection of material type. Surfaces are made more "passive" where chemical treatments are added to the manufacturing process. Passivation with acids such as nitric acid of stainless steel creates a less reactive oxide layer; this has been shown to improve the biocompatibility process. One added benefit to passivation is it serves as a means for removing foreign material from the surface, such as bacteria or biofilms (Blumenfeld \& Bargar, 2006). Passivation can also be used to surface-modify natural or synthetic polymer biomaterial substrates for meniscal tear applications. For example, albumin, where the resulting surface passivation has been shown to reduce and prevent clotting (Kaur, 2017; Hanker \& Giammara, 1988).

\section{Role of biomaterials in meniscal repair}

An article by Abrams et al. (2013) has shown that while there was no increase in the overall number of meniscal procedures, over a seven-year period there has been an $11.4 \%$ increase in isolated meniscal repairs and a $48.3 \%$ increase in meniscal repairs in combination with ACL reconstruction. This sharp increase in meniscal repair treatment is mainly due to the increased knowledge in the importance of the preservation of the meniscus to maintain normal knee function and prevent osteoarthritis. It has been shown that following meniscal repair, peak contact pressures are similar to that experienced with an intact meniscus (Bedi et al., 2010). Unfortunately, it is estimated that currently only $20 \%$ of all meniscal tears are repairable. Tears in the meniscal periphery (i.e., the red-red vascular zone) are most likely to heal whereas those in the meniscal avascular zone (i.e., the white-white zone) 
are unlikely to heal and those in the red-white zone have the potential to heal (Belzer \& Cannon, 1993; Noyes \& Barber-Westin, 2012). Besides vascularisation, tear type and various patient characteristics can influence decision making on treatment options and success of a meniscal repair. Typically, tears that are less than $2 \mathrm{~cm}$ in length, longitudinal and acute are more amendable to repair than larger tears (Taylor \& Rodeo, 2013; Laible, Stein \& Kiridly, 2013). Meniscal repairs are also not typically recommended for degenerative tears and thus repair success is typically superior in young patients (less than 50 years of age) (Laible, Stein \& Kiridly, 2013). When appropriately performed, meniscal repairs provide considerable improvements in terms of clinical outcome and osteoarthritis prevention compared to a partial meniscectomy (Stein et al., 2010). Thus, finding ways to increase the number of meniscal tears that can be treated by meniscal reparation is of great importance.

Vascularisation in the meniscus tissue is of high relevance to biomaterial design. From prenatal development up until after birth, the meniscus is fully vascularised. Following this, from the age of ten, vascularisation reduces to $30 \%$ of the meniscus and at maturity the meniscus only in the peripheral region of approximately $10 \%$ of the tissue. Vascularisation represents another challenge in meeting the requirements of success for biomaterial implantation as a meniscus operation. Vascular endothelial growth factor enhances the blood vessel density in peri-implant spaces. Biomaterial scaffolds of knee menisci exist in a highly challenging environment as little vascular support is provided in this region of the body. Electrospinning of polymeric fibres can be produced to support other engineering applications such as blood vessel, tendons, meniscus and cartilage (Xu et al., 2004). Some authors have used unique biodegradable nanofibers as a scaffold to support blood vessel engineering. They have demonstrated that fibres of $500 \mathrm{~nm}$ with an aligned topography is able to mimic the circumferential orientation of cells and fibrils (Leong et al., 2009). The authors have postulated that macrophage within the CES produce angiogeneic growth factors that potentially stimulates vascularisation.

\section{Role of biomaterials in meniscal replacement/regeneration}

Owing to the limited percentage of meniscal tears that can be repaired and the poor clinical results with untreated symptomatic meniscal injuries and partial meniscectomy, biomaterial synthetic and allogeneic (genetically dissimilar) interacting biomaterials have been investigated to serve as a matrix to lead meniscal regeneration medicine, particularly as a cellular support.

\section{Hydrogels}

Using a biomaterial that has the ability to seamlessly integrate in to water matrices is another attractive property in regenerative medicine applications for meniscal repair. Hydrogels are one such material with a considerable water based content; using hydrated polymer networks capable of absorbing and retaining fluids. Hydrogels are determined by their monomeric composition, crosslinking density and polymerisation ability. Due to the crosslinking chemistry the polymer remains insoluble in solution. The insolubility, along with the high hydration threshold, make hydrogels appealing to use for human tissue mimetics (Kobayashi, Chang \& Oka, 2005). As an example, some authors have used a 
poly (vinyl alcohol) hydrogel with a water content of approximately $90 \%$ to produce knee implants using a rabbit model (Makris, Hadidi \& Athanasiou, 2011). The implant replaced the whole lateral meniscus over two years. In a subsequent study, the hydrogel implant was not able to prevent damage to articular cartilage but was able to reduce progression of meniscal decay. Some of the new and emerging biomaterial types have been shown in Table 1.

\section{Chitin}

Chitin sutures are an emerging material of choice for improvement of the mechanical properties of a knee healing process (Brittberg et al., 1994). Owing to its favourable mechanical properties, chitin has been used for applications that require exceptional integrity and physical strength in surgical sutures, some new medical textiles and even as bone substitute materials.

\section{Nanofibres}

Electrospun scaffolds are also another emerging biomaterial that has begun to be used for cellular adhesion applications in regenerative medicine. The fibres have the ability to mimic both anisotropy of fibrous tissues and withstand high load forces that are imposed on the tissue during physiological motions (Ionescu \& Mauck, 2012). The electrospun biomaterials can also be tailored to produce various size, shapes and makeup (for example coaxial materials) will influence cell interactions and the cells will begin to proliferate and adhere and finally deposit matrix on to the fibre network. These interactions provide improved mechanical properties for the biomaterial scaffold over time. Fibres can be collected on to rotating drums or flat collection plates, depending on the order, orientation and architectures that they are required. Cells typically are seeded on to these scaffolds and cultured over time in vitro. In a study by Passaretti et al. (2001) tensile modulus was seen to improve on fibre aligned scaffolds some 7 -fold higher than disorganised fibres approaching the value of a normal meniscus. Essentially, the authors determined that cells prefer to align on ordered scaffold fibres rather than disorganised arrangements. Further to these findings, internal organisation in the form of sheet fibres can also be arranged for tissue-mimicking structures. Specifically, for meniscal tissue engineering, cells can be isolated, expanded and manually seeded on to the surfaces of electrospun scaffolds prior to an implantation operation, expediting the regenerative process. Cells along with host cells will migrate on to the newly implanted scaffold and deposit proteoglycan and collagen. Some implantation methods require surgery prior to this implant step to isolate the cells prior to seeding, maturation and implantation.

\section{Biodegradable polymers}

Some of the more current treatment methods for repair of meniscal tears are somewhat indifferent for positive results and outcomes. Tissue adhesives are a promising alternative, owing to their ease of application and minimal tissue trauma. Co-polymeric tissue adhesives have been shown to have adhesive strengths of $40-50 \mathrm{kPa}$ and hold edges of meniscal tears together during healing periods. These results indicate that copolymers are able to improve tissue capacity for self-repair specific for meniscal applications. Other authors have used 
Table 1 Summary of biomaterial studies used in meniscus research.

\begin{tabular}{|c|c|c|c|c|c|}
\hline Biomaterial used & Author & $\begin{array}{l}\text { Engineering } \\
\text { region }\end{array}$ & Success(es) & Species model & Ramifications \\
\hline \multicolumn{6}{|l|}{ Synthetic polymers } \\
\hline \multirow[t]{2}{*}{ Hydrogels } & $\begin{array}{l}\text { Kim\& Healy } \\
\text { (2003) }\end{array}$ & $\begin{array}{l}\text { Meniscus tissue } \\
\text { engineering }\end{array}$ & $\begin{array}{l}\text { Maintained } 90 \% \text { water content } \\
\text { that are not degraded by pro- } \\
\text { teases. The hydrogels used in } \\
\text { this study were incorporated } \\
\text { with non-reducible collagen } \\
\text { crosslink, pyridinoline. }\end{array}$ & Mammalian & $\begin{array}{l}\text { Peptide linked hydrogels have } \\
\text { the ability to be tailored to cre- } \\
\text { ate environment responsive arti- } \\
\text { ficial extracellular matrices that } \\
\text { are degraded by proteases. }\end{array}$ \\
\hline & $\begin{array}{l}\text { Rey-Rico, } \\
\text { Cucchiarini } \\
\& \text { Madry (2017) }\end{array}$ & $\begin{array}{l}\text { Meniscus tissue } \\
\text { engineering }\end{array}$ & $\begin{array}{l}\text { Review article providing results } \\
\text { on specific } 3 \mathrm{D} \text { microenviron- } \\
\text { ments using hydrogels. Many } \\
\text { hydrogel polymers were used in } \\
\text { this paper. }\end{array}$ & $\begin{array}{l}\text { Human and } \\
\text { animal models }\end{array}$ & $\begin{array}{l}\text { Hydrogels can be used as a plat- } \\
\text { form for precision and targeted } \\
\text { meniscus tissue engineering }\end{array}$ \\
\hline \multirow[t]{2}{*}{ Polygolic acid } & $\begin{array}{l}\text { Buma et al. } \\
\text { (2004) }\end{array}$ & $\begin{array}{l}\text { Meniscus tissue } \\
\text { repair }\end{array}$ & $\begin{array}{l}\text { Optimal pore geometry realised } \\
(15-25 \mu \mathrm{m})\end{array}$ & Canine & $\begin{array}{l}\text { Autologous meniscus cells seem } \\
\text { to be the optimal cell source } \\
\text { for tissue engineering. Research } \\
\text { should be stimulated to demon- } \\
\text { strate suitability of other cell } \\
\text { lines for meniscal repair. }\end{array}$ \\
\hline & $\begin{array}{l}\text { Ibarra et al. } \\
\text { (1997) }\end{array}$ & $\begin{array}{l}\text { Tissue engineered } \\
\text { meniscal tissue repair }\end{array}$ & $\begin{array}{l}\text { Used to replace massive tears or } \\
\text { completely resected menisci }\end{array}$ & Bovine & $\begin{array}{l}\text { A pivotal paper to show that au- } \\
\text { tologous cells could eventually } \\
\text { be used to replace allografts for } \\
\text { meniscus transplantation. }\end{array}$ \\
\hline
\end{tabular}


Table 1 (continued)

\begin{tabular}{|c|c|c|c|c|c|}
\hline Biomaterial used & Author & $\begin{array}{l}\text { Engineering } \\
\text { region }\end{array}$ & Success(es) & Species model & Ramifications \\
\hline \multicolumn{6}{|l|}{ Natural Polymers } \\
\hline \multirow[t]{2}{*}{$\begin{array}{l}\text { Collagen- } \\
\text { glycosaminoglycan } \\
\text { (GAG) }\end{array}$} & $\begin{array}{l}\text { Mueller et al. } \\
\text { (1999) }\end{array}$ & $\begin{array}{l}\text { Regeneration ap- } \\
\text { proaches to knee } \\
\text { meniscus }\end{array}$ & $\begin{array}{l}\text { Type II GAG matrix increased } \\
\text { DNA content and cellular re- } \\
\text { sponse to the matrix over } 3 \\
\text { weeks }\end{array}$ & Canine & $\begin{array}{l}\text { Type II matrix for the number } \\
\text { of cells and the higher GAG syn- } \\
\text { thesis of type II matrices com- } \\
\text { mend further investigation and } \\
\text { regeneration of meniscus in } \\
\text { vivo. }\end{array}$ \\
\hline & $\begin{array}{l}\text { McCorry \& } \\
\text { Bonassar (2017) }\end{array}$ & $\begin{array}{l}\text { Tissue engineering } \\
\text { for meniscal repair }\end{array}$ & $\begin{array}{l}\text { Mesenchymel stem cells in- } \\
\text { creased the GAG and collagen } \\
\text { production in both co-culture } \\
\text { and monoculture groups in a } 4 \\
\text { week study. }\end{array}$ & Bovine & $\begin{array}{l}\text { MSC lacks fibre organisation } \\
\text { capability. The study suggests } \\
\text { that GAG production and fi- } \\
\text { bre formation are largely linked, } \\
\text { therefore co-culture techniques } \\
\text { can be used to balance synthetic } \\
\text { properties and matrix modelling } \\
\text { capability. }\end{array}$ \\
\hline \multirow[t]{2}{*}{ Collagen sponge } & $\begin{array}{l}\text { Walsh et al. } \\
\text { (1999) }\end{array}$ & $\begin{array}{l}\text { Medial meniscus } \\
\text { repair }\end{array}$ & $\begin{array}{l}\text { Collagen sponge acted as a scaf- } \\
\text { fold producing abundant tissue } \\
\text { repair. }\end{array}$ & Canine & $\begin{array}{l}\text { Degenerative changes were } \\
\text { present in both groups indicat- } \\
\text { ing biomechanical function was } \\
\text { compromised. }\end{array}$ \\
\hline & $\begin{array}{l}\text { Murakami et al. } \\
\text { (2017) }\end{array}$ & $\begin{array}{l}\text { Meniscal scaffold } \\
\text { structure and repair }\end{array}$ & $\begin{array}{l}\text { Collagen sponges demonstrated } \\
\text { greater strength. At } 12 \text { weeks } \\
\text { stress and compression testing } \\
\text { was performed, lower inflam- } \\
\text { mation was noted in all sam- } \\
\text { ples coated with PGA. Foreign } \\
\text { body multinucleated giant cells } \\
\text { in implanted groups appeared in } \\
\text { weeks } 8 .\end{array}$ & Lapine & $\begin{array}{l}\text { Meniscal scaffolds using PGA } \\
\text { should possess biological and } \\
\text { biomechanical functions. The } \\
\text { PGA coating was a beneficial } \\
\text { property of the scaffold and of- } \\
\text { fers excellent biomechanical } \\
\text { function, regeneration and ulti- } \\
\text { mately less inflammation in this } \\
\text { material type. }\end{array}$ \\
\hline $\begin{array}{l}\text { Copolymeric } \\
\text { (L-lactide/epsilon- } \\
\text { caprolactone) }\end{array}$ & $\begin{array}{l}\text { De Groot et al. } \\
\text { (1997) }\end{array}$ & Meniscal repair & $\begin{array}{l}\text { Copolymer implants demon- } \\
\text { strated improved adhesion; fi- } \\
\text { brocartilage was affected of the } \\
\text { compression modulus. The } \\
\text { copolymer was degradable. }\end{array}$ & Canine & $\begin{array}{l}\text { Tearing problems usually asso- } \\
\text { ciated with sutures were partly } \\
\text { circumnavigated, this paper } \\
\text { paves the way for more work in } \\
\text { meniscal prostheses including } \\
\text { transplantation. }\end{array}$ \\
\hline
\end{tabular}


amphiphilic copolymers based on polyethylene glycol, trimethylene carbonate and citric acid to synthesise end-functionalised hexamethylene diisocyanate to form biodegradable hyper-branched tissue adhesives. The work showcases resorbable tissue materials for meniscus repair. The materials have excellent mechanical and adhesive properties that could be adjusted through variation of the composition of the copolymers (Bochynska et al., 2016c). Regenerative engineering converges a number of research areas and is truly multidisciplinary inclusive of tissue engineering, advanced materials, stem cell science and developmental biology to regenerate complex tissues from menisci to whole limbs (Narayanan et al., 2016). Clinical applications of tissue engineering technologies are still relatively restricted owing in part to the limited number of biomaterials that are approved for human use. While many biomaterials have been developed, their translation into practice has been extremely slow. Consequently, many researchers are still using biodegradable choices that were approved some 30 years ago. Most degradable biomaterials used to date comprise of synthetic polyesters:

- Poly(L-lactic acid) PLLA;

- Poly(L-glyolic acid) PLGA; and

- Biological polymers such as: alginate or chitosan, collagen or fibrin (Middleton \& Tipton, 2000).

Polyester-based polymers are clearly an excellent candidate as a synthetic biodegradable and bio-absorbable material for medical applications. The use of synthetic polyesters as biomaterials allow the unique control of the morphology, mechanical properties and degradation profiles measured through the monomer selection, polymer composition informed through the copolymer and homopolymer, stereo-complexation and also the molecular weight. In an excellent review by Brannigan and Dove, degradation mechanisms has been discussed in detail, in a clinical research capacity-these parameters are of paramount importance to understand the behaviour of the material in vitro or in vivo. The authors discuss enzymatic, oxidative, and physical degradation. Brannigan \& Dove (2017) discuss the use and importance of polyester type Poly-HDPE scaffolds with an interconnected porous structure for cartilage regeneration. In their work, neocartilage formation within a synthetic polyester scaffold based on polymerisation of high internal phase emulsions were used. The fabrication of polyHIPE polymers (PHP) was ordered to have highly porous giving structure to the cartilage with a higher potential in force wear. Another example of the use of biodegradable polymers in meniscal repair research includes, poly lactic acid or L-PLA is used in menisca reconstruction in a study using canines, the presence of macrophages, fibroblasts, giant cells and lymphocytes were observed to be attaching to the material. From this study it seems that biocompatibility reduces when the degradation process ensues. This degradation property therefore promoted inflammatory responses and thus rejection (Jones et al., 2002). 


\section{Discovery of new biomaterials-beyond state of the art}

The next phase in developing knee meniscal biomaterials for replacement and or regeneration applications extends to the design, discovery and evaluation of bioactive materials.

Bioactive meniscal materials have been used with some significantly exciting and promising results. For example, bioactive scaffolds have been shown to modulate local ECM density to improve repair (Shin, Jo \& Mikos, 2003). A novel biphasic collagen scaffold and shown to support meniscal repair in vivo to support meniscal cell ingrowth but also producing ECM in vitro by Howard et al. (2016). The authors have shown that the addition of PRP enhanced scaffold enhanced healing (Howard et al., 2016). Other emerging materials which could show potential in meniscal repair include: cartilage matrix is also a promising material for cartilage regeneration given the emerging evidence supporting its chondroinductive character. The cartilage matrix is a promising material for hyaline cartilage tissue engineering applications and has been shown that cell derived matrix and ECM materials and have been demonstrated to show established decellularisation, representing an excellent and promising choice of new material for future direction. (Redman, Oldfield \& Archer, 2005). A drawback so far is that the FDA regulatory approval may affect the decision to use a native or cell-derived matrix. To expedite FDA approval, a full chemical decellularisation of allogeneic matrix may be used-this way, removal of cells ensures no cross-species interactions (Sutherland et al., 2015). For example, allogeneic cells from bone marrow can be used in cardiac repair (Lemcke et al., 2017).

Initially, this is a relatively straightforward process whereby advanced synthesis of new materials can be performed. The difficulty lies with producing the novel activity and evaluation of the behaviour of the material in the biological system. Adapting the surface properties through the addition of synthetic peptides and or molecular drugs can yield thousands of candidate materials for testing. This approach has already been realised in the form of library derived screening techniques using commercially available methacrylate monomers-influencing attachment, growth, proliferation and differentiation of human embryonic stem cells (Anderson, Levenberg \& Langer, 2004).

Further developments in biomaterials will continue to expand at the interface of nanotechnology. Understanding the tribological interaction with the surrounding interface of the human body is an approach that is being realised using the "bottom-up" approach (Zur et al., 2011). The bottom up approach will develop novel, self-assembling and environment reactive biomaterials. In particular, self-assembling peptides offer a new approach owing to the large variety of sequences that can be produced by chemical synthesis. These advances include the design of short peptides that have the ability to resemble nanofilaments which are compatible in vitro, without rejection. The use of peptides in polymeric materials allows for resistance in concentration, $\mathrm{pH}$ or level of divalent cation variability (Hartgerink, Beniash \& Stupp, 2002).

The use of combinational gene therapy and biomaterial approaches is a recent technique to remedy meniscal lesions formed when orthopaedic surgery and loss of the meniscus has accelerated in the patient. The lack of therapeutic options suggests there is a need for improved treatments to enhance meniscal tear repair treatments/operations. 
Combinational approaches may also provide strategies to support this remedy (Cucchiarini et al., 2016). Gene therapy, can be directly applied as a combination or direct approach to meniscal repair strategies. A recent evaluation on gene therapy with cell and tissue engineering-based approaches demonstrates a six strategy approach: (a) directly using gene transfer vectors (Elsler et al., 2012), (b) administering genetically modified cells (Nakagawa et al., 2015), which could be fraught upon in some researching countries, continents, (c) implanting the biocompatible material that can deliver the recombinant factor, as we have seen rejection may be a potential problem with this result, (d) applying autologous platelet-rich plasma or fibrin clotting factors, (e) providing a biomaterial that delivers a gene transfer vector, (f) transplanting a material seeded with cells, again, we envisage a potential rejection with this treatment.

\section{Stem cell approaches}

Exciting new techniques are emerging as non-invasive approaches to meniscal tear correction using stem cells. The promising use of new tissue engineering approaches have incorporated natural biomaterials made from extracellular matrices of decellularised tissues from the heart, lung and bone for example (Yuan et al., 2017). The use of a scaffold or 'shell' to align stem cells upon in a given feature is fast becoming attractive. Decullularisation preserves the molecular composition with tissue specific molecules including structural and mechanical features present in the original tissue. The preservation step will aid in guiding the behaviour of the therapeutic cells and facilitate tissue development when implanted, non-invasively to the meniscal tear region.

In vitro studies have also been used to investigate tissue surface modification with collagenase to prime the surface where the addition of the TGF-beta3 cells has been proven to increase the number of cells present in meniscal tears repaired with newly developed tissue adhesives such as isocyanate-terminated block polymers. For example, Bochynske et al. have used cylindrical explants harvested from bovine menisci, the explants were simulated to possesses a full thickness-tear where the explants were then removed and glued back to the defect. In addition, the repair constructs were then culture with and without the addition of TGF-beta3 and assessed for their histological appearances. The histological staining of the constructs confirmed that cytotoxicity was not an issue and after 28 days, meniscal cells were present in the contact glues (Bochyniska et al., 2016b). The results demonstrate that the use of TGF-beta 3 induces thicker cell numbers round the edges of the annulus of the explants and also appears to be a promising treatment for tears using these glue types.

\section{Biomimetics}

One final, prominent field emerging in material science lies with biomimetic biomaterial approaches (Chapman et al., 2014). Biomimetic materials are materials that have been directly replicated from nature to produce a solution to a specific problem. Some synthetic polymers may be able to provide a more biomimetic environment than the previously discussed hydrogel approach. Functionalising hydrogels using chemistry is one strategy that requires future investigation. Hydrogels have the ability to create a more 'native' microenvironment for cells in a particular area of the body-i.e., the knee. For 
example, scaffolds with biomimetics have been developed for tissue engineering based on a multidisciplinary approach using engineering of biomaterials and nano/micro structuring of the defect tissues. The use of 3D bioprinting is considered to be conventional however, the technique has allowed for traditional fabrication methods for porous bone and cartilage regeneration to be taken in new directions using gas forming, soluble particle leaching or freeze drying. Newer methods to generate porous scaffolds using biodegradable polymers include using gas forming of porogens (ammonium bicarbonate particles). Injectable hydrogels using click chemistry (high yielding, wide in scope molecules) have also shown to be highly advantageous for local delivery of bioactive molecules, ease of handing and reduced invasiveness, these techniques have been demonstrated to be potentially used in 3D bioprinting (Jo, Kim \& Noh, 2012). The use of hand held 3D matrix printing using a bio-pen has allowed for in-situ printing and repair to take place. This will be a major development in regenerative medicine (Di Bella et al., 2017). The most recent and emerging areas for biomimetic medical materials are (Chen et al., 2016): (1) 3D bioprinting (focussed on medical materials); (2) designing nano/micro technologies; (3) surface modification of biomaterials for their cellular interaction ability; (4) clinical aspects of biomaterials for cartilage focussing on cells, scaffolds and cytokines (Fratzl \& Weinkamer, 2007). The traditional methods still have many advantages (Chen et al., 2016), but as 3D printing techniques develop coupled with new developments in chemistry of the biomaterial, the use of biomimetic design and the inherent properties linked to biocompatibility will enable more advanced developments in the future of meniscal repair.

\section{CONCLUSIONS}

Evidently, the diversity of biomaterials for meniscal applications is immense. Many approaches to mimicking the structure and function of the ECM have been conceived. It is crucial that these advances continue to be investigated for their ability to interact within a biological system. As biomaterials advance and new methods of delivery develop, inclusive of minimal invasive surgery move forward-the field of meniscal tears and treatment will be greatly advanced and if not greatly reduced in the coming decade.

\section{ADDITIONAL INFORMATION AND DECLARATIONS}

\section{Funding}

The authors received no funding for this work.

\section{Competing Interests}

Robert J. Brown is an employee of Advanced Medical Solutions, Plymouth, UK.

\section{Author Contributions}

- Crystal O. Kean and James Chapman conceived and designed the experiments, performed the experiments, analyzed the data, contributed reagents/materials/analysis tools, wrote the paper, prepared figures and/or tables, reviewed drafts of the paper. 
- Robert J. Brown performed the experiments, analyzed the data, contributed reagents/materials/analysis tools, wrote the paper, prepared figures and/or tables, reviewed drafts of the paper.

\section{Data Availability}

The following information was supplied regarding data availability:

No raw code exists for this work.

\section{REFERENCES}

Abrams GD, Frank RM, Gupta AK, Harris JD, McCormick FM, Cole BJ. 2013. Trends in meniscus repair and meniscectomy in the United States 2005-2011. The American Journal of Sports Medicine 41(10):2333-2339 DOI 10.1177/0363546513495641.

Anderson DG, Levenberg S, Langer R. 2004. Nanoliter-scale synthesis of arrayed biomaterials and application to human embryonic stem cells. Nature Biotechnology 22(7):863-866 DOI 10.1038/nbt981.

Anderson JM, Rodriguez A, Chang DT. 2008. Foreign body reaction to biomaterials. Seminars in Immunology 20(2):86-100 DOI 10.1016/j.smim.2007.11.004.

Apicella A, Apicella D, Syed J, Aversa R. 2017. Innovative biomaterials in bone tissue engineering and regenerative medicine. In: Tatullo M, ed. MSCs and innovative biomaterials in dentistry. Stem cell biology and regenerative medicine. New York: Humana Press.

Arnoczky SP, Warren RF. 1982. Microvasculature of the human meniscus. The American Journal of Sports Medicine 10(2):90-95 DOI 10.1177/036354658201000205.

Baek J, Sovani S, Choi W, Jin S, Grogan SP, D’Lima DD. 2017. Meniscal tissue engineering using aligned collagen fibrous scaffolds: comparison of different human cell sources. Tissue Engineering Part A Epub ahead of print DOI 10.1089/ten.TEA.2016.0205.

Bahraminasab M, Farahmand F. 2017. State of the art review on design and manufacture of hybrid biomedical materials: hip and knee prostheses. Proceedings of the Institution of Mechanical Engineers, Part H: Journal of Engineering in Medicine 231(9):785-813 DOI 10.1177/0954411917705911.

Baino F, Perero S, Miola M, Ferraris M. 2017. Advances in science and technology. Vol. 102. Zurich, 24-28.

Baker BE, Peckham AC, Pupparo F, Sanborn JC. 1985. Review of meniscal injury and associated sports. The American Journal of Sports Medicine 13(1):1-4 DOI 10.1177/036354658501300101.

Balakrishnan B, Soman D, Payanam U, Laurent A, Labarre D, Jayakrishnan A. 2017. A novel injectable tissue adhesive based on oxidized dextran and chitosan. Acta Biomaterialia 53:343-354 DOI 10.1016/j.actbio.2017.01.065.

Baratz ME, Fu FH, Mengato R. 1986. Meniscal tears: the effect of meniscectomy and of repair on intraarticular contact areas and stress in the human knee. A preliminary report. The American Journal of Sports Medicine 14(4):270-275 DOI 10.1177/036354658601400405. 
Beamer BS, Walley KC, Okajima S, Manoukian OS, Perez-Viloria M, DeAngelis JP, Ramappa AJ, Nazarian A. 2017. Changes in contact area in meniscus horizontal cleavage tears subjected to repair and resection. Arthroscopy: The Journal of Arthroscopic \& Related Surgery 33(3):617-624 DOI 10.1016/j.arthro.2016.09.004.

Bedi A, Kelly NH, Baad M, Fox AJ, Brophy RH, Warren RF, Maher SA. 2010. Dynamic contact mechanics of the medial meniscus as a function of radial tear repair, and partial meniscectomy. The Journal of Bone and Joint Surgery. American Volume 92(6):1398-1408 DOI 10.2106/JBJS.I.00539.

Bedi A, Kelly N, Baad M, Fox AJ, Ma Y, Warren RF, Maher SA. 2012. Dynamic contact mechanics of radial tears of the lateral meniscus: implications for treatment. Arthroscopy 28(3):372-381 DOI 10.1016/j.arthro.2011.08.287.

Bellabarba C, Bush-Joseph C, Bach Jr B. 1997. Patterns of meniscal injury in the anterior cruciate-deficient knee: a review of the literature. American Journal of Orthopedics 26(1):18-23.

Belzer JP, Cannon W. 1993. Meniscus tears: treatment in the stable and unstable knee. Journal of the American Academy of Orthopaedic Surgeons 1(1):41-47 DOI 10.5435/00124635-199309000-00006.

Bergmann CP, Stumpf A. 2013. Dental ceramics: microstructure, properties and degradation. VII. Berlin Heidelberg: Springer-Verlag, 84.

Berthiaume M-J, Raynauld J-P, Martel-Pelletier J, Labonté F, Beaudoin G, Bloch DA, Choquette D, Haraoui B, Altman RD, Hochberg M. 2005. Meniscal tear and extrusion are strongly associated with progression of symptomatic knee osteoarthritis as assessed by quantitative magnetic resonance imaging. Annals of the Rheumatic Diseases 64(4):556-563 DOI 10.1136/ard.2004.023796.

Blumenfeld TJ, Bargar WL. 2006. Early aseptic loosening of a modern acetabular component secondary to a change in manufacturing. The Journal of Arthroplasty 21(5):689-695 DOI 10.1016/j.arth.2005.10.010.

Bochyńska AI, Hannink G, Janssen D, Buma P, Grijpma DW. 2016a. Development of a fast curing tissue adhesive for meniscus tear repair. Journal of Materials Science: Materials in Medicine 28(1):Article 1 DOI 10.1007/s10856-016-5790-6.

Bochyńska AI, Hannink G, Verhoeven R, Grijpma DW, Buma P. 2016b. The effect of tissue surface modification with collagenase and addition of TGF- $\beta 3$ on the healing potential of meniscal tears repaired with tissue glues in vitro. Journal of Materials Science: Materials in Medicine 28(1):Article 22 DOI 10.1007/s10856-016-5832-0.

Bochyńska AI, Van Tienen TG, Hannink G, Buma P, Grijpma DW. 2016c. Development of biodegradable hyper-branched tissue adhesives for the repair of meniscus tears. Acta Biomaterialia 32:1-9 DOI 10.1016/j.actbio.2015.12.018.

Brannigan RP, Dove AP. 2017. Synthesis properties and biomedical applications of hydrolytically degradable materials based on aliphatic polyesters and polycarbonates. Biomaterials Science 5(1):9-21 DOI 10.1039/C6BM00584E. 
Brittberg M, Lindahl A, Nilsson A, Ohlsson C, Isaksson O, Peterson L. 1994. Treatment of deep cartilage defects in the knee with autologous chondrocyte transplantation. New England Journal of Medicine 331(14):889-895 DOI 10.1056/NEJM199410063311401.

Bròdano GB, Giavaresi G, Lolli F, Salamanna F, Parrilli A, Martini L, Griffoni C, Greggi T, Arcangeli E, Pressato D. 2014. Hydroxyapatite-based biomaterials versus autologous bone graft in spinal fusion: an in vivo animal study. Spine 39(11):E661-E668 DOI 10.1097/BRS.0000000000000311.

Browner BD. 2009. Skeletal trauma: basic science, management, and reconstruction. London: Elsevier Health Sciences.

Bruns J, Kahrs J, Kampen J, Behrens P, Plitz W. 1998. Autologous perichondral tissue for meniscal replacement. Journal of Bone \& Joint Surgery, British Volume 80(5):918-923 DOI 10.1302/0301-620X.80B5.8023.

Buma P, Ramrattan NN, Van Tienen TG, Veth RPH. 2004. Tissue engineering of the meniscus. Biomaterials 25(9):1523-1532 DOI 10.1016/S0142-9612(03)00499-X.

Calvo JN-M, Elices M, Guinea GV, Pérez-Rigueiro J, Arroyo-Hernández M. 2017. Stability and activity of lactate dehydrogenase on biofunctional layers deposited by activated vapor silanization (AVS) and immersion silanization (IS). Applied Surface Science 416:965-970 DOI 10.1016/j.apsusc.2017.04.123.

Cameron JC, Saha S. 1997. Meniscal allograft transplantation for unicompartmental arthritis of the knee. Clinical Orthopaedics and Related Research 337:164-171 DOI 10.1097/00003086-199704000-00018.

Chapman J, Hellio C, Sullivan T, Brown R, Russell S, Kiterringham E, Le Nor L, Regan F. 2014. Bioinspired synthetic macroalgae: examples from nature for antifouling applications. International Biodeterioration \& Biodegradation 86:6-13 DOI 10.1016/j.ibiod.2013.03.036.

Chapman J, Le Nor L, Brown R, Kitteringham E, Russell S, Sullivan T, Regan F. 2013. Antifouling performances of macro-to micro-to nano-copper materials for the inhibition of biofouling in its early stages. Journal of Materials Chemistry $B$ 1(45):6194-6200 DOI 10.1039/c3tb21285h.

Chen C, Bang S, Cho Y, Lee S, Lee I, Zhang S, Noh I. 2016. Research trends in biomimetic medical materials for tissue engineering: 3D bioprintingsurface modification, nano/micro-technology and clinical aspects in tissue engineering of cartilage and bone. Biomaterials Research 20(1):Article 10 DOI 10.1186/s40824-016-0057-3.

Chen JP, Cheng TH. 2006. Thermo-responsive chitosan-graft-poly ( $\mathrm{N}$-isopropylacrylamide) injectable hydrogel for cultivation of chondrocytes and meniscus cells. Macromolecular Bioscience 6(12):1026-1039 DOI 10.1002/mabi.200600142.

Chen F-M, Zhang M, Wu Z-F. 2010. Toward delivery of multiple growth factors in tissue engineering. Biomaterials 31(24):6279-6308 DOI 10.1016/j.biomaterials.2010.04.053.

Chevalier J. 2006. What future for zirconia as a biomaterial? Biomaterials 27(4):535-543 DOI 10.1016/j.biomaterials.2005.07.034.

Clayton RA, Court-Brown CM. 2008. The epidemiology of musculoskeletal tendinous and ligamentous injuries. Injury 39(12):1338-1344 DOI 10.1016/j.injury.2008.06.021. 
Cooper DE, Arnoczky SP, Warren RF. 1990. Arthroscopic meniscal repair. Clinics in Sports Medicine 9(3):589-607.

Cucchiarini M, McNulty AL, Mauck RL, Setton LA, Guilak F, Madry H. 2016. Advances in combining gene therapy with cell and tissue engineering-based approaches to enhance healing of the meniscus. Osteoarthritis and Cartilage 24(8):1330-1339 DOI 10.1016/j.joca.2016.03.018.

De Groot J, Zijlstra F, Kuipers H, Pennings A, Klompmaker J, Veth R, Jansen H. 1997. Meniscal tissue regeneration in porous 5050 copoly (l-lactide/ $\epsilon$-caprolactone) implants. Biomaterials 18(8):613-622 DOI 10.1016/S0142-9612(96)00169-X.

Di Bella C, Duchi S, O’Connell CD, Blanchard R, Augustine C, Yue Z, Thompson F, Richards C, Beirne S, Onofrillo C. 2017. In-situ handheld 3D bioprinting for cartilage regeneration. Journal of Tissue Engineering and Regenerative Medicine Epub ahead of print DOI 10.1002/term.2476.

Elsler S, Schetting S, Schmitt G, Kohn D, Madry H, Cucchiarini M. 2012. Effective safe nonviral gene transfer to preserve the chondrogenic differentiation potential of human mesenchymal stem cells. Journal of Gene Medicine 14(7):501-511.

Emmert MY, Hoerstrup SP. 2017. Challenges in translating tissue engineered heart valves into clinical practice. European Heart Journal 38(9):619-621 DOI 10.1093/eurheartj/ehx075.

Engler AJ, Sen S, Sweeney HL, Discher DE. 2006. Matrix elasticity directs stem cell lineage specification. Cell 126(4):677-689 DOI 10.1016/j.cell.2006.06.044.

Englund M, Roos EM, Lohmander LS. 2003. Impact of type of meniscal tear on radiographic and symptomatic knee osteoarthritis: a sixteen-year followup of meniscectomy with matched controls. Arthritis and Rheumatism 48(8):2178-2187 DOI 10.1002/art.11088.

Feucht MJ, Bigdon S, Bode G, Salzmann GM, Dovi-Akue D, Südkamp NP, Niemeyer P. 2015. Associated tears of the lateral meniscus in anterior cruciate ligament injuries: risk factors for different tear patterns. Journal of Orthopaedic Surgery and Research 10(1):Article 34 DOI 10.1186/s13018-015-0184-X.

Fratzl P, Weinkamer R. 2007. Nature's hierarchical materials. Progress in Materials Science 52(8):1263-1334 DOI 10.1016/j.pmatsci.2007.06.001.

Freed LE, Marquis J, Nohria A, Emmanual J, Mikos A, Langer R. 1993. Neocartilage formation in vitro and in vivo using cells cultured on synthetic biodegradable polymers. Journal of Biomedical Materials Research 27(1):11-23 DOI 10.1002/jbm.820270104.

Gage BE, McIlvain NM, Collins CL, Fields SK, Comstock RD. 2012. Epidemiology of 6.6 million knee injuries presenting to United States emergency departments from 1999 through 2008. Academic Emergency Medicine 19(4):378-385 DOI 10.1111/j.1553-2712.2012.01315.x.

Green Jr WT. 1977. Articular cartilage repair: behavior of rabbit chondrocytes during tissue culture and subsequent allografting. Clinical Orthopaedics and Related Research 124:237-250.

Greiner AM, Jäckel M, Scheiwe AC, Stamow DR, Autenrieth TJ, Lahann J, Franz CM, Bastmeyer M. 2014. Multifunctional polymer scaffolds with adjustable pore 
size and chemoattractant gradients for studying cell matrix invasion. Biomaterials 35(2):611-619 DOI 10.1016/j.biomaterials.2013.09.095.

Greis PE, Bardana DD, Holmstrom MC, Burks RT. 2002. Meniscal injury: I. Basic science and evaluation. Journal of the American Academy of Orthopaedic Surgeons 10(3):168-176 DOI 10.5435/00124635-200205000-00003.

Grogan SP, Pauli C, Lotz MK, D’Lima DD. 2017. Relevance of meniscal cell regional phenotype to tissue engineering. Connective Tissue Research 58(3-4):259-270 DOI 10.1080/03008207.2016.1268604.

Hall M, Wrigley TV, Metcalf BR, Hinman RS, Dempsey AR, Mills PM, Cicuttini FM, Lloyd DG, Bennell KL. 2013. A longitudinal study of strength and gait after arthroscopic partial meniscectomy. Medicine and Science in Sports and Exercise 45(11):2036-2043 DOI 10.1249/MSS.0b013e318299982a.

Hall M, Wrigley TV, Metcalf BR, Hinman RS, Dempsey AR, Mills PM, Cicuttini FM, Lloyd DG, Bennell KL. 2014. A longitudinal study of impact and early stance loads during gait following arthroscopic partial meniscectomy. Journal of Biomechanics 47(12):2852-2857 DOI 10.1016/j.jbiomech.2014.07.029.

Hallab N, Link HD, McAfee PC. 2003. Biomaterial optimization in total disc arthroplasty. Spine 28 20S:S139-S152.

Han JH, Song JG, Kwon JH, Kang KW, Shah D, Nha K-W. 2015. Spontaneous healing of a displaced bucket-handle tear of the lateral meniscus in a child. Knee Surgery \& Related Research 27(1):65-67 DOI 10.5792/ksrr.2015.27.1.65.

Hanker JS, Giammara BL. 1988. Biomaterials and biomedical devices. Science 242:885-892 DOI 10.1126/science.3055300.

Hartgerink JD, Beniash E, Stupp SI. 2002. Peptide-amphiphile nanofibers: a versatile scaffold for the preparation of self-assembling materials. Proceedings of the National Academy of Sciences of the United States of America 99(8):5133-5138 DOI 10.1073/pnas.072699999.

Howard D, Tanase E, Wardale J, Henson F. 2016. A novel biphasic scaffold supports meniscal tissue repair in ex vivo and in vivo models. Musculoskeletal Regeneration 2:e1411 DOI 10.14800/mr.1411.

Ibarra C, Jannetta C, Vacanti CA, Cao Y, Kim TH, Upton J, Vacanti JP. 1997. Tissue engineered meniscus: a potential new alternative to allogeneic meniscus transplantation. Transplantation Proceedings 29(1-2):986-988

DOI 10.1016/S0041-1345(96)00337-5.

Ihn JC, Kim SJ, Park IH. 1993. In vitro study of contact area and pressure distribution in the human knee after partial and total meniscectomy. International Orthopaedics 17(4):214-218.

Ionescu LC, Mauck R.L. 2012. Porosity and cell preseeding influence electrospun scaffold maturation and meniscus integration in vitro. Tissue Engineering Part A 19(34):538-547 DOI 10.1089/ten.tea.2012.0052.

Jiang D, Zhao L-H, Tian M, Zhang J-Y, Yu J-K. 2012. Meniscus transplantation using treated xenogeneic meniscal tissue: viability and chondroprotection study in 
rabbits. Arthroscopy: The Journal of Arthroscopic \& Related Surgery 28(8):1147-1159

DOI 10.1016/j.arthro.2012.01.001.

Jo S, Kim S, Noh I. 2012. Synthesis of in situ chondroitin sulfate hydrogel through phosphine-mediated Michael type addition reaction. Macromolecular Research 20:968-976 DOI 10.1007/s13233-012-0138-7.

Jones HP, Lemos MJ, Wilk RM, Smiley PM, Gutierrez R, Schepsis AA. 2002. Two-year follow-up of meniscal repair using a bioabsorbable arrow. Arthroscopy 18(1):64-69.

Jung J-Y, Jee W-H, Park MY, Lee S-Y, Kim J-M. 2012. Meniscal tear configurations: categorization with 3D isotropic turbo spin-echo MRI compared with conventional MRI at 3 T. American Journal of Roentgenology 198(2):W173-W180 DOI 10.2214/AJR.11.6979.

Kaur G. 2017. Biomaterials influencing human lives. In: Bioactive glasses. Series in BioEngineering, Cham: Springer.

Kim S, Healy KE. 2003. Synthesis and characterization of injectable poly (Nisopropylacrylamide-co-acrylic acid) hydrogels with proteolytically degradable crosslinks. Biomacromolecules 4(5):1214-1223 DOI 10.1021/bm0340467.

Kim JG, Lee YS, Bae TS, Ha JK, Lee DH, Kim YJ, Ra HJ. 2013. Tibiofemoral contact mechanics following posterior root of medial meniscus tear repair, meniscectomy, and allograft transplantation. Knee Surg, Sports Traumatol, Arthroscopy 21(9):2121-2125 DOI 10.1007/s00167-012-2182-4.

King W, Bendele A, Marohl T, Woodell-May J. 2017. Human blood-based antiinflammatory solution inhibits osteoarthritis progression in a meniscal-tear rat study. Journal of Orthopaedic Research 35(10):2260-2268 DOI 10.1002/jor.23528.

Kobayashi M, Chang Y-S, Oka M. 2005. A two year in vivo study of polyvinyl alcohol-hydrogel (PVA-H) artificial meniscus. Biomaterials 26(16):3243-3248 DOI 10.1016/j.biomaterials.2004.08.028.

Laible C, Stein DA, Kiridly DN. 2013. Meniscal repair. The Journal of the American Academy of Orthopaedic Surgeons 21:204-213 DOI 10.5435/JAAOS-21-04-204.

Lee SJ, Aadalen KJ, Malaviya P, Lorenz EP, Hayden JK, Farr J, Kang RW, Cole BJ. 2006. Tibiofemoral contact mechanics after serial medial meniscectomies in the human cadaveric knee. The American Journal of Sports Medicine 34(8):1334-1344 DOI 10.1177/0363546506286786.

Lemcke H, Gaebel R, Skorska A, Voronina N, Lux CA, Petters J, Sasse S, Zarniko N, Steinhoff G, David R. 2017. Mechanisms of stem cell based cardiac repair-gap junctional signaling promotes the cardiac lineage specification of mesenchymal stem cells. Scientific Reports 7(1):Article 9755 DOI 10.1038/s41598-017-10122-6.

Leong MF, Rasheed MZ, Lim TC, Chian KS. 2009. In vitro cell infiltration and in vivo cell infiltration and vascularization in a fibrous highly porous poly (D, L-lactide) scaffold fabricated by cryogenic electrospinning technique. Journal of Biomedical Materials Research Part A 91(1):231-240 DOI 10.1002/jbm.a.32208.

Lloyd AW, Faragher RG, Denyer SP. 2001. Ocular biomaterials and implants. Biomaterials 22(8):769-785 DOI 10.1016/S0142-9612(00)00237-4. 
Majewski M, Susanne H, Klaus S. 2006. Epidemiology of athletic knee injuries: a 10-year study. The Knee 13(3):184-188 DOI 10.1016/j.knee.2006.01.005.

Makris EA, Hadidi P, Athanasiou KA. 2011. The knee meniscus: structure-function pathophysiology, current repair techniques, and prospects for regeneration. Biomaterials 32(30):7411-7431 DOI 10.1016/j.biomaterials.2011.06.037.

Mardis HK, Kroeger R. 1988. Ureteral stents materials. 15(3):471-479.

Mauck RL, Burdick JA. 2015. From repair to regeneration: biomaterials to reprogram the meniscus wound microenvironment. Annals of Biomedical Engineering 43(3):529-542 DOI 10.1007/s10439-015-1249-z.

McCorry MC, Bonassar LJ. 2017. Fiber development and matrix production in tissueengineered menisci using bovine mesenchymal stem cells and fibrochondrocytes. Connective Tissue Research 58(3-4):329-341 DOI 10.1080/03008207.2016.1267152.

McDermott ID, Masouros SD, Amis AA. 2008. Biomechanics of the menisci of the knee. Current Orthopaedics 22(3):193-201 DOI 10.1016/j.cuor.2008.04.005.

McLeod MM, Gribble P, Pfile KR, Pietrosimone BG. 2012. Effects of arthroscopic partial meniscectomy on quadriceps strength: a systematic review. Journal of Sport Rehabilitation 21(3):285-295 DOI 10.1123/jsr.21.3.285.

Middleton JC, Tipton AJ. 2000. Synthetic biodegradable polymers as orthopedic devices. Biomaterials 21(23):2335-2346 DOI 10.1016/S0142-9612(00)00101-0.

Mota C, Labardi M, Trombi L, Astolfi L, D’Acunto M, Puppi D, Gallone G, Chiellini F, Berrettini S, Bruschini L. 2017. Design fabrication and characterization of composite piezoelectric ultrafine fibers for cochlear stimulation. Materials \& Design 122:206-219 DOI 10.1016/j.matdes.2017.03.013.

Mueller SM, Shortkroff S, Schneider TO, Breinan HA, Yannas IV, Spector M. 1999. Meniscus cells seeded in type I and type II collagen-GAG matrices in vitro. Biomaterials 20(8):701-709 DOI 10.1016/S0142-9612(98)00189-6.

Murakami T, Otsuki S, Nakagawa K, Okamoto Y, Inoue T, Sakamoto Y, Sato H, Neo M. 2017. Establishment of novel meniscal scaffold structures using polyglycolic and poly-l-lactic acids. Journal of Biomaterials Applications 32(2):150-161 DOI 10.1177/0885328217713631.

Nakagawa Y, Muneta T, Kondo S, Mizuno M, Takakuda K, Ichinose S, Tabuchi T, Koga H, Tsuji K, Sekiya I. 2015. Synovial mesenchymal stem cells promote healing after meniscal repair in microminipigs. Osteoarthritis and Cartilage 23(6):1007-1017 DOI 10.1016/j.joca.2015.02.008.

Narayanan G, Vernekar VN, Kuyinu EL, Laurencin CT. 2016. Poly (lactic acid)-based biomaterials for orthopaedic regenerative engineering. Advanced Drug Delivery Reviews 107:247-276 DOI 10.1016/j.addr.2016.04.015.

Nasab MB, Hassan MR. 2010. Metallic biomaterials of knee and hip-a review. Trends in Biomaterials \& Artificial Organs 24(1):69-82.

Nielsen AB, Yde J. 1991. Epidemiology of acute knee injuries: a prospective hospital investigation. The Journal of Trauma 31(12):1644-1648

DOI 10.1097/00005373-199112000-00014. 
Noyes FR, Barber-Westin SD. 2012. Management of meniscus tears that extend into the avascular region. Clinics in Sports Medicine 31(1):65-90

DOI 10.1016/j.csm.2011.08.009.

Ohishi T, Torikai E, Suzuki D, Banno T, Honda Y. 2010. Arthroscopic treatment of a medial meniscal cyst using a posterior trans-septal approach: a case report. Sports Medicine, Arthroscopy, Rehabilitation, Therapy \& Technology 2(1):Article 25 DOI 10.1186/1758-2555-2-25.

Paschos NK, Lim N, Hu JC, Athanasiou KA. 2017. Functional properties of native and tissue-engineered cartilage toward understanding the pathogenesis of chondral lesions at the knee: a bovine cadaveric study. Journal of Orthopaedic Research 35(11):2452-2464 DOI 10.1002/jor.23558.

Passaretti D, Silverman RP, Huang W, Kirchhoff CH, Ashiku S, Randolph MA, Yaremchuk MJ. 2001. Cultured chondrocytes produce injectable tissue-engineered cartilage in hydrogel polymer. Tissue Engineering 7(6):805-815

DOI 10.1089/107632701753337744.

Pihl K, Englund M, Lohmander LS, Jørgensen U, Nissen N, Schjerning J, Thorlund JB. 2017. Signs of knee osteoarthritis common in 620 patients undergoing arthroscopic surgery for meniscal tear. Acta Orthopaedica 88(1):90-95 DOI 10.1080/17453674.2016.1253329.

Redman S, Oldfield S, Archer C. 2005. Current strategies for articular cartilage repair. European Cells \& Materials 9:23-32 DOI 10.22203/eCM.v009a04.

Reid D, Leigh W, Wilkins S, Willis R, Twaddle B, Walsh S. 2017. A 10-year retrospective review of functional outcomes of adolescent anterior cruciate ligament reconstruction. Journal of Pediatric Orthopaedics 37(2):133-137

DOI 10.1097/BPO.0000000000000594.

Rey-Rico A, Cucchiarini M, Madry H. 2017. Hydrogels for precision meniscus tissue engineering: a comprehensive review. Connective Tissue Research 58(3-4):317-328 DOI 10.1080/03008207.2016.1276576.

Roos H, Lauren M, Adalberth T, Roos EM, Jonsson K, Lohmander LS. 1998. Knee osteoarthritis after meniscectomy: prevalence of radiographic changes after twenty-one years compared with matched controls. Arthritis and Rheumatism 41(4):687-693 DOI 10.1002/1529-0131(199804)41:4<687::AID-ART16>3.0.CO;2-2.

Salata MJ, Gibbs AE, Sekiya JK. 2010. A systematic review of clinical outcomes in patients undergoing meniscectomy. The American Journal of Sports Medicine 38(9):1907-1916 DOI 10.1177/0363546510370196.

Sanen K, Martens W, Georgiou M, Ameloot M, Lambrichts I, Phillips J. 2017. Engineered neural tissue with Schwann cell differentiated human dental pulp stem cells: potential for peripheral nerve repair? Journal of Tissue Engineering and Regenerative Medicine Epub ahead of print DOI 10.1002/term.2249.

Scholes CJ, Lynch JT, Ebrahimi M, Fritsch BA, Parker DA. 2017. Gait adaptations following multiple-ligament knee reconstruction occur with altered knee kinematics during level walking. Knee Surgery, Sports Traumatology, Arthroscopy 25(5):1489-1499 DOI 10.1007/s00167-016-4104-3. 
Seedhom BB, Dowson D, Wright V. 1974. Functions of the menisci. A preliminary study. Annals of the Rheumatic Diseases 33(1):111 DOI 10.1136/ard.33.1.111.

Shin H, Jo S, Mikos AG. 2003. Biomimetic materials for tissue engineering. Biomaterials 24(24):4353-4364 DOI 10.1016/S0142-9612(03)00339-9.

Stein T, Mehling AP, Welsch F, Von Eisenhart-Rothe R, Jager A. 2010. Long-term outcome after arthroscopic meniscal repair versus arthroscopic partial meniscectomy for traumatic meniscal tears. The American Journal of Sports Medicine 38(8):1542-1548 DOI 10.1177/0363546510364052.

Sturnieks DL, Besier TF, Hamer PW, Ackland TR, Mills PM, Stachowiak GW, Podsiadlo P, Lloyd DG. 2008a. Knee strength and knee adduction moments following arthroscopic partial meniscectomy. Medicine and Science in Sports and Exercise 40(6):991-997 DOI 10.1249/MSS.0b013e318167812a.

Sturnieks DL, Besier TF, Lloyd DG. 2011. Muscle activations to stabilize the knee following arthroscopic partial meniscectomy. Clinical Biomechanics 26(3):292-297 DOI 10.1016/j.clinbiomech.2010.11.003.

Sturnieks DL, Besier TF, Mills PM, Ackland TR, Maguire KF, Stachowiak GW, Podsiadlo P, Lloyd DG. 2008b. Knee joint biomechanics following arthroscopic partial meniscectomy. Journal of Orthopaedic Research 26(8):1075-1080 DOI 10.1002/jor.20610.

Sun C, Wang X, Mao C, Shen J. 2014. Novel biomaterials for human health: hemocompatible polymeric micro-and nanoparticles and their application in biosensor. In: Tiwari A, ed. Advanced healthcare materials. Hoboken: John Wiley \& Sons, Inc.

Sutherland AJ, Converse GL, Hopkins RA, Detamore MS. 2015. The bioactivity of cartilage extracellular matrix in articular cartilage regeneration. Advanced Healthcare Materials 4(1):29-39 DOI 10.1002/adhm.201400165.

Tamimi F, Torres J, Al-Abedalla K, Lopez-Cabarcos E, Alkhraisat MH, Bassett DC, Gbureck U, Barralet JE. 2014. Osseointegration of dental implants in 3D-printed synthetic onlay grafts customized according to bone metabolic activity in recipient site. Biomaterials 35(21):5436-5445 DOI 10.1016/j.biomaterials.2014.03.050.

Taylor SA, Rodeo SA. 2013. Augmentation techniques for isolated meniscal tears. Current Reviews in Musculoskeletal Medicine 6(2):95-101

DOI 10.1007/s12178-013-9165-z.

Temenoff JS, Mikos AG. 2000. Review: tissue engineering for regeneration of articular cartilage. Biomaterials 21(5):431-440 DOI 10.1016/S0142-9612(99)00213-6.

Thevenot P, Hu W, Tang L. 2008. Surface chemistry influence implant biocompatibility. Current Topics in Medicinal Chemistry 8(4):270-280 DOI 10.2174/156802608783790901.

Vander Roest MJ, Merryman WD. 2016. A developmental approach to induced pluripotent stem cells-based tissue engineered heart valves. Future Cardiology 13(1) DOI 10.2217/fca-2016-0071.

Van Egmond N, Hannink G, Janssen D, Vrancken A, Verdonschot N, Van Kampen A. 2017. Relaxation of the MCL after an Open-Wedge High Tibial Osteotomy results in decreasing contact pressures of the knee over time. Knee Surg, Sports Traumatol, Arthroscopy 25(3):800-807 DOI 10.1007/s00167-017-4438-5. 
Vongpatanasin W, Hillis LD, Lange RA. 1996. Prosthetic heart valves. New England Journal of Medicine 335(6):407-416 DOI 10.1056/NEJM199608083350607.

Waizy H, Diekmann J, Weizbauer A, Reifenrath J, Bartsch I, Neubert V, Schavan R, Windhagen H. 2014. In vivo study of a biodegradable orthopedic screw (MgYREZralloy) in a rabbit model for up to 12 months. Journal of Biomaterials Applications 28(5):667-675 DOI 10.1177/0885328212472215.

Walczak J, Shahgaldi F, Heatley F. 1998. In vivo corrosion of 316L stainless-steel hip implants: morphology and elemental compositions of corrosion products. Biomaterials 19(1):229-237 DOI 10.1016/S0142-9612(97)00208-1.

Walker PS, Erkman MJ. 1975. The role of the menisci in force transmission across the knee. Clinical Orthopaedics and Related Research 109:184-192 DOI 10.1097/00003086-197506000-00027.

Walsh CJ, Goodman D, Caplan AI, Goldberg VM. 1999. Meniscus regeneration in a rabbit partial meniscectomy model. Tissue Engineering 5(4):327-337 DOI 10.1089/ten.1999.5.327.

Xu C, Inai R, Kotaki M, Ramakrishna S. 2004. Aligned biodegradable nanofibrous structure: a potential scaffold for blood vessel engineering. Biomaterials 25(5):877-886 DOI 10.1016/S0142-9612(03)00593-3.

Yamamoto K, Takagi M, Ito H. 2016. Emerging insights on surgical techniques and biomaterials for total hip and knee arthroplasty. BioMed Research International 2016:Article 1496529 DOI 10.1155/2016/1496529.

Yuan X, Wei Y, Villasante A, Ng JJD, Arkonac DE, Chao P-HG, Vunjak-Novakovic G. 2017. Stem cell delivery in tissue-specific hydrogel enabled meniscal repair in an orthotopic rat model. Biomaterials 132:59-71 DOI 10.1016/j.biomaterials.2017.04.004.

Zhao D, Witte F, Lu F, Wang J, Li J, Qin L. 2017. Current status on clinical applications of magnesium-based orthopaedic implants: a review from clinical translational perspective. Biomaterials 112:287-302 DOI 10.1016/j.biomaterials.2016.10.017.

Zur G, Linder-Ganz E, Elsner JJ, Shani J, Brenner O, Agar G, Hershman EB, Arnoczky SP, Guilak F, Shterling A. 2011. Chondroprotective effects of a polycarbonateurethane meniscal implant: histopathological results in a sheep model. Knee Surgery, Sports Traumatology, Arthroscopy 19(2):255-263 DOI 10.1007/s00167-010-1210-5. 